Portland State University

PDXScholar

Summer 2021

\title{
The Journey to El Norte: An Analysis of Gendered Violence on Central American Migrant Trails
}

\author{
Rachel A. Adams
}

Follow this and additional works at: https://pdxscholar.library.pdx.edu/honorstheses

Part of the Central American Studies Commons, and the Women's Studies Commons Let us know how access to this document benefits you.

\section{Recommended Citation}

Adams, Rachel A., "The Journey to El Norte: An Analysis of Gendered Violence on Central American Migrant Trails" (2021). University Honors Theses. Paper 1129.

https://doi.org/10.15760/honors.1160

This Thesis is brought to you for free and open access. It has been accepted for inclusion in University Honors Theses by an authorized administrator of PDXScholar. Please contact us if we can make this document more accessible: pdxscholar@pdx.edu. 
The Journey to El Norte:

An Analysis of Gendered Violence on Central American Migrant Trails

By Rachel Adams

An Undergraduate Honors Thesis submitted in partial fulfillment of the requirements for the degree of

\author{
Bachelor of Arts \\ in \\ University Honors \\ and \\ International Development
}

Advised by:

Leopoldo Rodriguez, Ph.D.

Portland State University 2021 


\section{The Journey to El Norte:}

\section{An Analysis of Gendered Violence on Central American Migrant Trails}

\section{Abstract}

This thesis aims to investigate the violence encountered by Central American women, both at home and when they seek to migrate to the US. We examine the conditions faced by Central American women leading them to take risks as they emigrate from their countries of origin. First, we analyze the violence that women face in their countries of origin. Next, we discuss the violence that women encounter on migrant corridors. Finally, we explore the obstacles that migrant women face when they arrive at the United States border itself. This thesis ultimately aims to provide information to the interdisciplinary field of migration in hopes that a better understanding will provide ways to address the repeated occurrence of these violent episodes. We hope this thesis will contribute to the migration literature providing new insight into how migration patterns relate to gender-based violence.

Keywords: migrant, women, violence, emigration, migration, Central America. 


\section{Background}

\section{Global Migration}

In the past few years, the world has experienced great transformations in its migration rates. Migration is the general process of moving from one place to another (Bachmann-Medick \& Kugele 123). A migrant is someone "who moves to a country other than that of his or her usual residence for a period of at least a year, so that the country of destination effectively becomes his or her new country of usual residence” (Mavroudi \& Nagel 5). Furthermore, immigration and emigration are terms that are used to describe specific movement and settlement across borders, immigration being movement to a destination country while emigration is movement out of a country of origin (Mavroudi \& Nagel 5). In the past few decades there have been large changes in migration patterns due to globalization and international mobility. According to the 2020 United Nations World Migration Report, the number of international migrants is estimated to be 272 million people globally which makes up 3.5 percent of the world's population (UN 2). Migration patterns are not consistent from country to country as migration flows concentrate to a small number of countries. Over one third of the world's migration population migrate from Mexico, India, the Russian Federation, China, Ukraine, Bangladesh, Pakistan, the United Kingdom, the Philippines, and Turkey (Mavroudi \& Nagel 9). Additionally, in terms of countries of destination the United States alone houses 20 percent of the world's migrants (Mavroudi \& Nagel 9).

A growing body of evidence suggests that changes in mobility are greatly attributed to broader global, economic, social, and political transformations (UN 1). Major migration and displacement events are often attributed to great hardship, extreme violence, trauma, and loss of life (UN 2). In terms of violence specifically, at the end of 2018, it was estimated that 41.3 
million people were displaced by conflict and violence globally, which was the highest amount recorded since the Internal Displacement Monitoring Centre (IDMC) began monitoring in 1998 (UN 43). Ultimately, migration is a vital response to adversity and violent obstacles.

\section{Central American Migration}

Central America is a region located South of Mexico made up of seven countries:

Guatemala, Belize, Honduras, El Salvador, Nicaragua, Costa Rica, and Panama. Every year, thousands of Central American migrants are forced to flee their homes and migrate to the United States. One of the most frequented migrant corridors in the world exists between Mexico and the United States. According to the Mexican Ministry of the Interior, 390,000 individuals migrated from Central America to Mexico in 2014, many of which further continued their journey to the United States_ — as it is the main migration destination for Mexico (Leyva-Flores et al. 2019). According to the 2020 United Nations World Migration Report, the largest migration corridors involving Latin America countries are between Mexico and the United States as well as between El Salvador, Honduras, and Guatemala to the United States (UN 97). Central American migrants travel from southern Mexico to the US-Mexico border which is approximately around 1,800 miles (see Figure 1). It is estimated that in April of 2021, 178,000 migrants arrived at the United States/Mexico border which was a record-breaking high in terms of monthly totals in the last two decades (BBC 2021). Furthermore, out of those migrants around 40 percent came from a Central American region called the Northern Triangle consisting of : Guatemala, El Salvador, and Honduras (BBC 2021). 


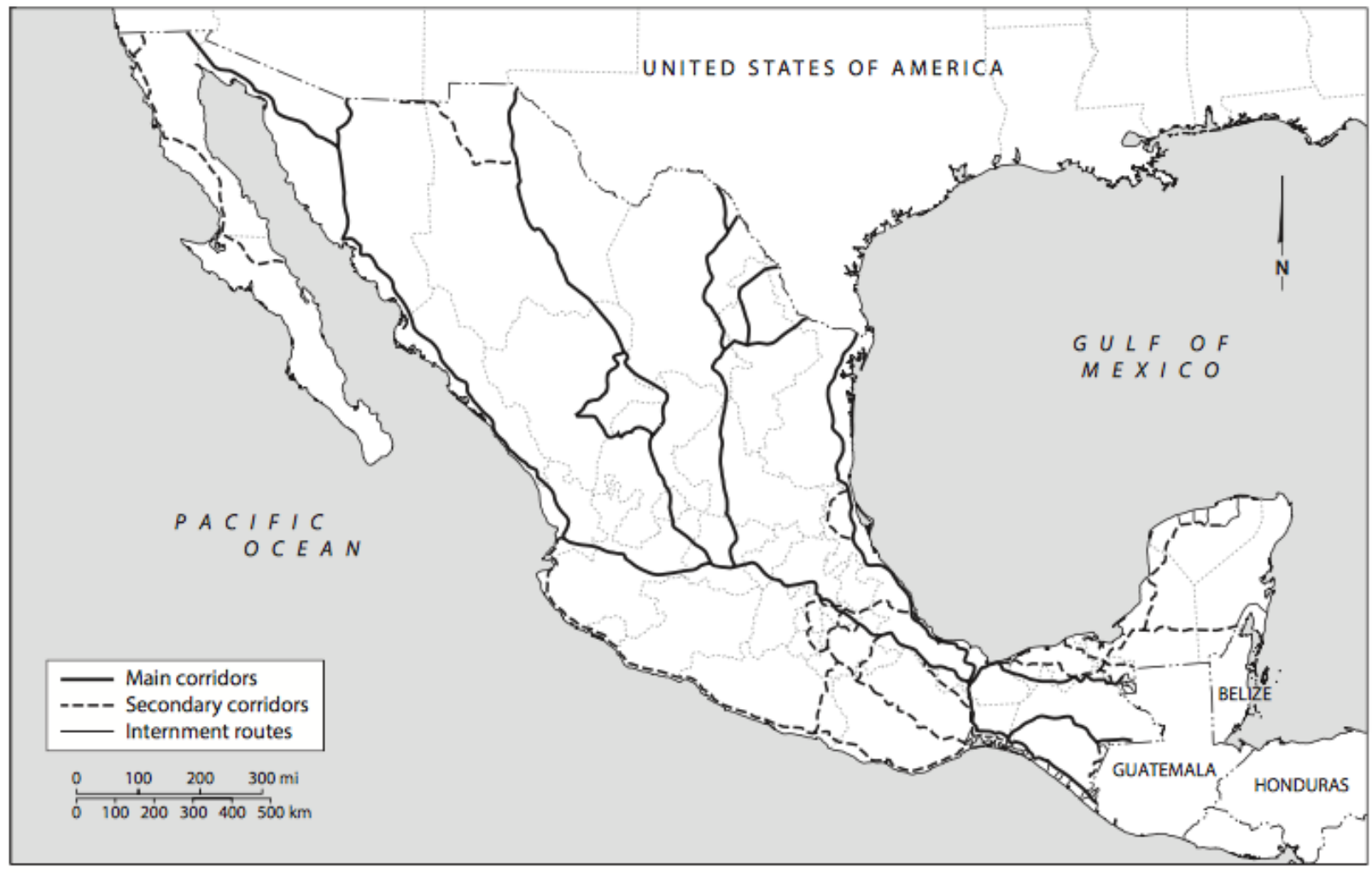

Figure 1 Map of Migrant Land Routes from Central America to the United States.

Source: Speed 2019

Migrants leave their countries of origin for a variety of reasons. According to the Food and Agriculture Organization of the United Nations (FAO) 2018, these reasons include: violence, insecurity, poverty, and family reunification (FAO 1). In the past few decades, there has been a significant increase in asylum seekers from Central America. Some more specific reasons for massive irregular emigration from countries in the "Northern Triangle" (El Salvador, Guatemala, and Honduras), as explored in the United Nations World Food Programme include: food insecurity, lack of economic opportunities, and violence (FAO 1). Additionally, the United Nations World Migration Report finds that socioeconomic conditions as well as generalized community-level violence are the largest contributors to emigration from Central American countries. In 2017, asylum claims from Mexico and Central America made up 54 percent of the 
total asylum claims for the United States (UN 105). Over 33,000 of those claims came from El Salvador as well as Guatemala who made up another 33,000 followed by Venezuela which made up around 27,500 claims (UN 105).

Throughout their journey to the United States, Central Americans have to pass through Mexico where they face harrowing challenges. These migrants, who often escape violence at home, often face further violence in their journey to the United States. Between 1998 and 2015, 6,571 Central American and Mexican migrants died in their attempt to cross the US/Mexico border (Leyva-Flores et al. 2019). In a cross-sectional study conducted in Mexico between 2009 and 2015, Leyva-Flores et al. (2019) found that out of a sample size of 12,023 migrants, 29.4 percent admitted to having experienced some form of violence. As Leyva-Flores et al. point out, these results are likely to understate the levels of violence prevalent on migrant corridors because migrants might be inclined to hide their traumatic experiences. Schmidt (2017) points out that the liminal spaces occupied by migrants on their journeys, result in high vulnerability and invisibility, making them perfect targets of increased violence. The violence migrants face is a multifaceted issue which must be studied in great depth in order to understand why people are willing to take risks to migrate.

\section{Women in Central America}

Central American women face severe gender inequality when compared to women in other countries in the world. Gender inequality and sexism is widely considered to have held the region back in terms of social and economic development. Ávalos (2016) argues that although Central American states have built health and educational reforms in order to create better access to education and health care, these reforms have not done enough in terms of addressing gender inequalities. Additionally, as the World Bank (2018) argues, although significant changes have 
been made, such changes have ultimately not evenly created significant economic opportunities for women in Central America compared to women in other countries in Latin America and the Caribbean. Further investment in education and healthcare are critical to minimizing the perpetuation of unequal gender opportunities.

In order to support their families, many women in Central America are forced into poor working conditions which forces them into even further poverty. Alarming statistics from the Northern Triangle countries (Honduras, Guatemala, and El Salvador) show that 70 percent of female workers lack access to protections like social security due to informal employment (Ávalos 1). In terms of legal frameworks, there are no laws in place to ensure that women get paid as much as men. Central American women also lack access to education. According to the World Bank (2016) maternal education correlates with reductions in certain risk factors such as "infant or child malnutrition, low birth weight, and failure to vaccinate children" (World Bank 17). On a global level, the importance of women's education was written in the United Nations Sustainable development goals, stating that education was an indicator of gender equality. According to The World Bank (2016), improvements on maternal education saved the lives of approximately 2.1 million children under the age of 5 worldwide from 1990 to 2009 (17). Increasing women's access to education will ultimately improve the livelihoods of all individuals in Central America. In order to guarantee success and sustainable development for the region, it is critical to prioritize access to both education and healthcare, thus, as Ávalos (2016) argues, this is associated with empowering women as agents of change. Overall, an increase in women's empowerment in Central America promotes economic development and the well-being of the region. 


\section{Significance}

Existing migration discourse has primarily examined how issues of violence may be heightened due to different factors including socioeconomic status, gender, age, and race. Scholarship on migration studies has mostly overlooked the physical encounters migrants face in their journeys to national borders. "Academic work that does unpack the journey tends to focus myopically on the border rather than the long-distance corridors that most migrants must traverse" (Speed 7). Additionally, scholarship tends to ignore those who lose their lives in the migration journey as a result of the violence that exists throughout migration corridors.

Discourse in United States is plagued with narratives that paint the United States-Mexico border as a "nightmare" of drug trafficking, terrorism, and illegal immigrants in an effort to contribute to the United States's "militarized regimes of social control” (Speed 11). However, migrant corridors are as dangerous as the borders themselves. As Schmidt (2017) argues, studying such topics “provide a broader understanding of women's experiences and strategies that can inform more humane migration policy and social programs better tailored to women's needs"(140). As explored by Schmidt (2017) and Speed (2020), gender-based violence is one of the factors pushing migrants to leave their countries of origin. If root causes of migration such as gender-based violence aren’t addressed, such violent events will continue to occur and asylum seekers will be put in dangerous situations when migrating. It is crucial to study and document these violent events through interdisciplinary work in order to find ways to avoid further deaths and create safer corridors for migrants.

This thesis will focus on the violence that Central American women face both in their countries of origin and as they migrate to the United States. Our aim is to understand how gender inequalities, and its expression in violence toward women, contribute to the migrant flow of 
Northern Triangle countries in Central America, and how episodes of violence follow women migrants throughout their journey into the United States. We will first look into the conditions that lead women to flee their countries. Second we will conduct an in-depth analysis of the conditions they face throughout their journey. Finally, we will highlight ways in which interdisciplinary efforts can help mitigate the impacts that migration has on Central American women. 


\section{Analysis}

\section{Violence Against Women in Central America}

Central America is facing a multifaceted problem surrounding violence. Criminal violence manifests itself in different ways originating from various social, political, economic and historical issues. Much of the violence occurs in Central America's northernmost countries often called the "Northern Triangle Countries" (El Salvador, Guatemala, and Honduras) (see Figure 2). According to The Wilson Center, the murder rates in this region are five times higher than in Mexico, making it the most dangerous region in the world outside regions of war (Wilson Center). Not only is Central America extremely poor with a Gross Domestic Product (GDP) per capita that does not surpass $\$ 4,000$ (Cruz 2015) but it has some of the highest homicide rates in the world. According to Schmidt (2017) El Salvador has the highest rate of homicides per capita in the world, and since 2011, Honduras has averaged 80 homicides per 100,000 inhabitants (Cruz 43). The United Nations Office of Drugs and Crime (UNODC) has identified eight areas of violence in the Northern Triangle Region : "drug trafficking, homicide, youth gangs, domestic violence, firearms trafficking, kidnapping, money laundering, and corruption” (Cruz 46).

Bozmoski (2021) finds that recent events, like the Covid-19 pandemic, have exacerbated gender-based violence. One factor that underlies increases in domestic abuse against women is lockdowns - which is further exacerbated by a corresponding increase in alcohol consumption. Although effects of the pandemic have heightened gender-based violence, there are many other 
multi-faceted factors that influence it.

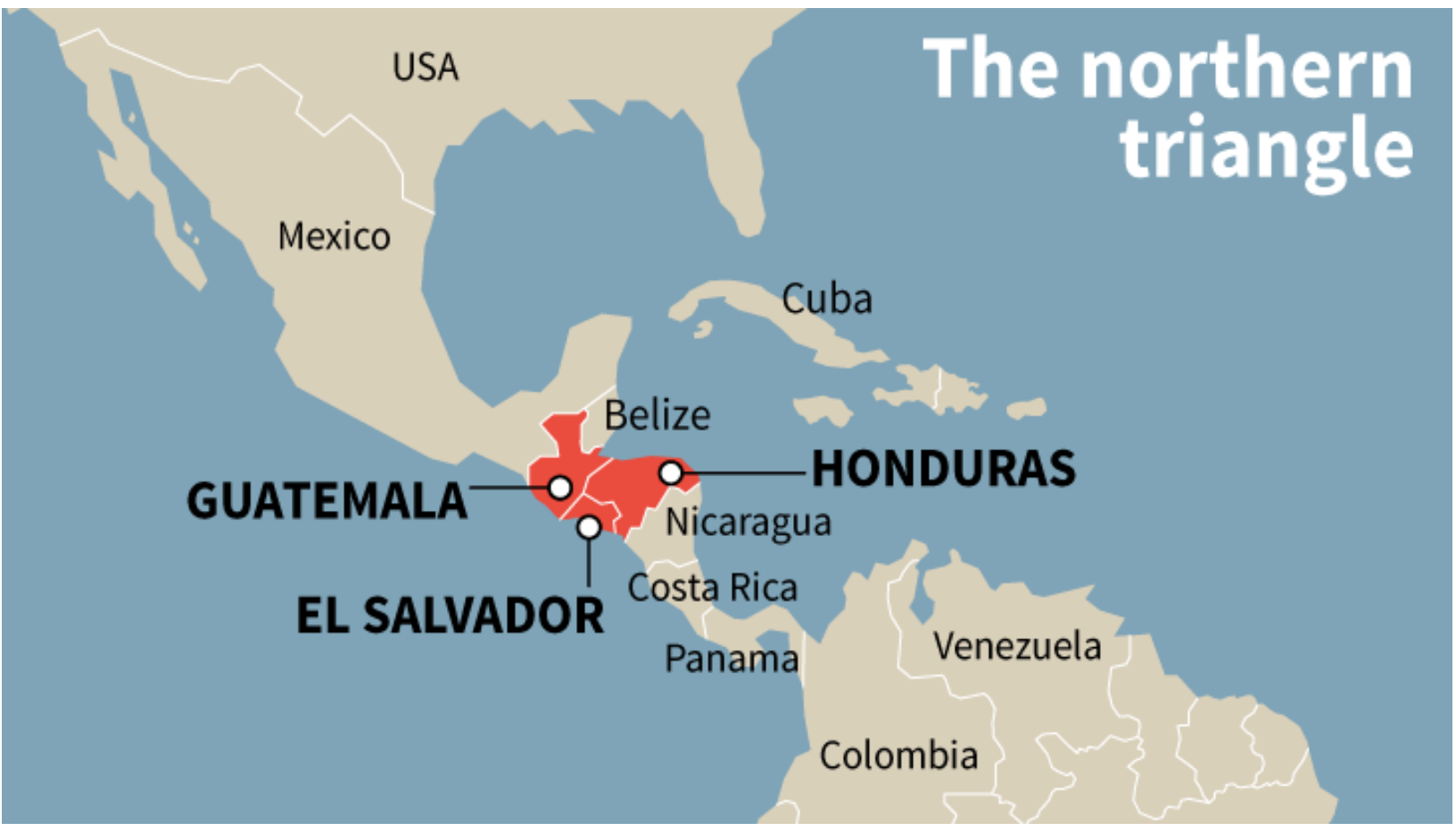

Figure 2: Central America's Northern Triangle. Source: Refugeeswelcomehome.org

Central America has experienced high levels of violence throughout its history. During the Spanish conquest local populations were subjugated by force. Brutal conditions and exploitation continued through the 300 years of colonial rule. Disease and forced labor resulted in the plummeting of indigenous populations, leading in some regions to the importation of African slaves. Independence from Spain in the 1820s made little difference to the bulk of the population, who essentially saw the Spanish monarchy replaced by oligarchic rule, retaining a highly stratified and unequal society.

Periods of oligarchic rule in the 1800s and early 1900s were followed and sustained by military dictatorships and authoritarian rule, with regimes in Guatemala and El Salvador facing widespread insurgency in the 1980s. Attempts at reform, as in the case of Árbenz's Guatemala, were met with the intervention of the United States on the side of the status-quo, eroding 
institutions and establishing impunity in the hands of the armed forces. The violence unleashed by these US-backed regimes on their own people has left profound scars in these nation's societies. As left-wing insurgents entered the political process in the 1990s, there was hope for peace, democratization, development, equity, and institutional reform. However, very little has changed in the past three decades, with violence and economic vulnerability increasing during this period.

The corruption that continues to exist today is a direct outcome of US-backed regimes which acted with impunity in the 1980s-1990s. Many scholars like Shifter (2012) and Sanchez (2006) argue that United State interventions during the Cold War destabilized the region, resulting in multifaceted violence that continues to occur. Shifter (2012) argues that Central America's failure to construct state institutions has allowed for criminal organizations to expand, gaining power and control. As Sanchez (2006) argues: “As elected governments lose control over public security, private groups emerge" (184). Central American states have experienced difficulties negotiating socially and politically with criminal entities who are gaining control over the region. States have had no choice but to resort to violence which has sparked harsh conflicts across Central America.

\section{Gendered Violence}

Much of the violence that occurs in Central America is gender related, disproportionately targeting women over men. Scholars who study the gender aspects of migration relate the reasons leading women to migrate to their social, economic, and political roles (López et al. 2021). Scholars like López et al. (2021) argue that interpersonal and institutional gendered violence are both significant reasons why women migrate from Central America. Furthermore, Menjívar (2011) considers violence against women to be multifaceted, providing four distinct 
areas: organized crime, interpersonal abuse, structural violence, and political violence. Each variable described by Menjívar alludes to a lack of security that stems from the prevalence of organized crime and corruption taking place across Central America. In the following section we will apply Menjívar's framework to analyze how different forms of violence affect the lives of Central American women.

Organized crime is an outcome of the "illicit activities" driven by profit-driven non-state groups attributed to Central America’s “war-torn” past (Shifter 5). Groups engaged in organized crime, such as gangs and drug cartels, often carry out violent "direct attacks" (López 4). According to the United Nations Office of Drugs and Crime, the countries in Central America's Northern triangle exhibit high levels of violence that are exacerbated by organized crime and drug activity (Gomez 53). Criminal networks operate outside the norms of the state and its legal system, often preventing citizens from having peaceful and safe lives. The flow of drugs, primarily cocaine from South America to the United States, is a major contributing factor to the presence of criminal organizations and the resulting violence. Cocaine trafficking is the most lucrative organized crime activity in Central America. The United States estimates that 90 percent of illicit drugs that cross into the country's borders pass through Mexico and Central America (Wilson Center, 1). Although Central America used to be a "refueling spot" for the transnational drug trade, in the past few decades it has become home to both storage and logistics centers of transnational drug trafficking groups (Gomez). Tension between territorial groups, trafficking groups, and Central American governments has sparked violence that affect everyday civilians. Narcos (drug traffickers) will do anything to get what they want to gain control. For example in May of 2011, there was a large massacre in the Petén region of Guatemala resulting 
in the murder and decapitation of 27 peasant farmers and their wives and kids. The attack was attributed to a battle between drug gangs who were fighting for control of the area.

Gangs are another aspect of organized crime in Central America. According to research conducted by the Wilson Center, Honduras has the largest population of gang members in North America. They have territorial control of certain neighborhoods, weakening security throughout Central America. Members of transnational gangs like the Mara Salvatrucha and Calle 18 “provide muscle”(Wilson Center 1) to drug smugglers in Mexico by gaining territory of certain areas where drugs are transported. Furthermore, lower level gangs assist in drug distribution called narcomenudeo which is a source of violence due to gang fights over territory.

Criminal organizations pose a threat to families, leading to gender violence. Drug cartels and gangs often rely on the recruitment of young children to expand their numbers and territory, oftentimes taking advantage of the socio-economic vulnerability of poorer households. According to a report published by Doctors Without Borders (DWB), the levels of endemic violence in Central America are attributed to systemic gang membership. Violence in the region exposes children to environments of violence like assault in murder. According to Doctors Without Borders (2019), gangs attract youth at a young age, "offering them protection and giving them access to resources as well as a sense of belonging” (2019). Criminal organizations also target families and threaten people's loved ones when they don't want to comply. Flor, a woman interviewed by López et al. (2021) left home after drug cartels slaughtered seven of her extended family members (López et al. 8). There had been a gang trying to recruit her son, so she sent him to the United States for protection. When the gang realized that he had been sent to the United States, they began to threaten Flor's immediate family. López quotes Flor: 
I can't risk them coming and killing them.... At the age of my little one over there — ten years old — they already put a finger on them. ... That's why I came [to the U.S. border], more than anything for my children. (López et al. 8)

Ultimately Flor decided to migrate from her country of origin to protect the safety and well-being of her children. Sometimes, women face no choice but to flee. Lucinda, a 24 year old Hondurian woman interviewed by Schmidt (2017) recalled being stalked and harassed by gang members who thought she and her brother were responsible for the death of her son's father. After repeated harassment and a physical altercation, Lucinda ended up fleeing in the middle of the night with her brother, leaving her son behind with her mother in Honduras. As Lucinda recalled: "No, I did not want to leave. But I had no choice. I had to leave because I have to keep my son safe" (Schmidt 146).

López et al. (2021) finds that organized crime exacerbates gender violence as gang members often coerce their young daughters into abusive sexual relationships. Another practice is to rape their rivals group's girlfriends, wives, daughters, and mothers (López et al.). When entering relationships with men who are involved in gang activity, women often experience extreme dehumanization and abuse. Gangs utilize sexual violence and exploitation to gain control of communities. López et al. (2021) interviewed a woman named Sylvia, from Guatemala, who talked about how she had to flee her country when a group of gangsters threatened to kill her whole family when her son refused to join their gang. The same group had murdered Sylvia's brother for not wanting to join a few years previously (López et al. 9). Overall, the growing presence of organized crime has heightened gender-based violence in Central America, affecting the safety and well-being of women and their families. Ultimately, 
migration becomes a solution for women who feel like their safety, and their family's safety, can only be guaranteed by fleeing.

Domestic violence is a form of interpersonal abuse which is a result of the normalization of gender norms in Central America. According to Menjívar (2011), the normalization of gender norms results in gender-based violence, particularly domestic violence. A study conducted in El Salvador in 2008 found that "violence, drinking, and womanizing were all constructs of maleness"(Menjívar 88) therefore they are all linked to gender-based violence and interpersonal abuse. During interviews with Guatemalan women, Menjíivar found that regardless of social and economic status, women reported experiencing both sexual, psychological, and physical abuse from their partners. Additionally, recent information released in the United Nations April 2020 policy brief titled "The Impact of Covid-19 on Women" indicates that lockdowns have heightened domestic abuse across Central America. The report specifies that Latin America has the highest rates of domestic abuse in the world representing 81 percent of cases globally (UN, 2020). The UN piece also reported that following lockdown, domestic abuse cases have gone up 175 percent (UN 2020). The Office for the Coordination of Human Affairs (OCHA) interviewed women on their experiences with gender-based violence. A 21-year old woman named Samya stated: "It [domestic abuse] is a more harmful disease than virus itself" (OCHA 1). Another woman lamented the lack of resources to combat domestic violence like helplines and safe spaces and considered this to be the result of Central American governments having failed to integrate proper response systems to domestic violence. Overall, government mandated lockdowns have forced women to spend more time with their abusers.

Gendered violence is also prevalent through domestic abuse. Many due to the ways that young teens and men are coerced by criminal groups to drink and partake in illegal activities, 
such as using drugs, leading to heightened domestic abuse rates. López et al. (2021) finds that gang activity results in men developing hypermasculinity which in turn results in domestic abuse of their wives and children (López et al. 9). Furthermore, when men get involved with criminal groups they are often prompted to rape, kidnap and kill women and children as a form of gang or cartel initiation. For example a 26-year old woman interviewed by López et al. named Samantha faced tremendous abuse from her partner when he joined a cartel. According to Samantha, her now ex-partner was forced to partake in drugs which led him to beat her. It got to the point where he threw her and their three children ages 5, 3, and 1 out on the streets. Later on, when Samantha attempted to escape the abuse her ex-partner kidnapped her but she was able to get away. At that point she decided to migrate in order to save her kids (López et al. 10). Another woman interviewed by Menjívar (2011) named Hortencia endured physical abuse from her husband, especially when he would drink. Hortencia describes the physical abuse as "the way things are around here" (Menjívar 92). Although much of the domestic violence that Hortensia endured was when she was alone, other family members, particularly men, were complicit because they allowed the abuse to continue. Another woman interviewed by Menjívar named Delfina talked about how no one would believe her when she spoke up about the physical abuse from her husband. "People don’t believe me, he’s so nice to everyone" she said (Menjívar 92). Samantha, Hortencia, and Delfina's stories are representative of a bigger group of women who experience domestic abuse as a result of the normalization of violence in Central America.

Gendered violence in the form of domestic abuse not only affects women, but it affects their children as well. López et al. et al. (2021) find that violence isolates women, particularly mothers who are overburdened with having to protect their children (López et al. 2). Through research conducted from 2019-2020 consisting of interviews with Central American and 
Mexican asylum-seeking mothers, López et al. (2021) finds that violence makes it difficult for women to properly take care of their children. Most of the women interviewed for López et al.'s study migrated in order to protect their children from violence. As Anita, a migrant mother from El Salvador who was interviewed by Schmidt (2017) is quoted saying: "To see your children without anything is nothing any mother should experience. I risk everything because I have lost everything. Without my children, I have nothing" (Schmidt 149). Ultimately, a common trend shown through literature indicates that women put up with violence and exploitation when it affects them solely, but once their kids are involved, they attempt to remove them from damaging contexts.

Structural violence manifests itself in different aspects of Central American women's lives. According to López et al. (2021) structural violence is related to social and economic conditions that emerge from the actions of social institutions that deny citizens their basic needs. Institutional failures have exacerbated suffering in Central America due to structural inequities, economic inequalities, and persistent poverty. As Menjívar (2011) argues, unlike physical violence structural violence "causes people to suffer harm indirectly, often through a slow and steady process” (Menjívar 32). As Sanchez (2006) further argues Central American government's policies have heightened “inequality, exclusion, poverty, and alienation”(180) which have in turn led to criminal activity and corruption as means to meet needs.

Those who grow up in poverty are more susceptible to violence and extortion. Social exclusion and economic isolation are large contributors to such violence. According to Sanchez (2006), Latin America has some of the highest rates of socioeconomic inequality in the world. Large swaths of the population face chronic poverty, unable to escape a life of poverty due to gaps in education, access to health care, access to clean water, and other forms of welfare 
(Sanchez 181). Sanchez explains that structural violence does not occur because people are poor, but rather because people are exposed over generations to conditions where they have no choice but to resort to violence. Women are particularly affected by structural violence because it gets in the way of them being able to protect and support the wellbeing of themselves and their families. According to López et al. (2021), many women are forced to support their families when their husbands leave or become victims of violence. Overall, structural inequalities have made women particularly likely to suffer from violence in Central America.

Among the worst instances of structural violence in Central America are femicides or gender-motivated murders. An ongoing femicide emergency has greatly affected the lives of women in the region. Although femicides are a global problem, they have become an increasing concern across Central America. In Ciudad Juárez, a US-Mexico border city, there have been many discoveries of tortured corpses of young women (Agnew). Since the bodies displayed evidence of sexual violence and no apparent motive, Agnew (2015) notes that such murders fall under the category of femicides. Many deaths are overlooked by officials because the victims are considered prostitutes or drug addicts, which forms a narrative of they "asked for it" (Agnew 429). This can be seen through alarming statistics presented by Folkerts et al. (2016) who find that the rate of femicides in Honduras went up 263 percent from 2005 to 2013 (1). Additionally, a Guatemalan newspaper reported that every 46 minutes there is a new sexual assault victim in Guatemala, which ammounted to 11,299 reported cases in 2015, a figure likely to be well below the real number (Folkerts et al). Femicides have been overlooked due to systemic failures to acknowledge gender violence. When faced with such extreme structural violence, many women choose to migrate and seek the protection of asylum in the US. 
Political violence is a result of a deeply entrenched sense of injustice at the hands of powerful political players and economic elites who have controlled the destiny of Central American societies. It stems from of a long, deep history of military forces protecting the interests of wealthy elites who were aligned with U.S. capitalist interests - particularly during the Cold War and in its wake. Political violence includes threats and physical violence like beatings, torture, and murder as a result of a person's political interests and activities. An example of Central American political violence was the assasination of Archbishop Oscar Romero who was murdered in El Salvador at the hands of paramilitary forces — trained by the U.S.—in 1980. Romero's assasination was a political attack fueled by vehement opposition to his liberation theology. Liberation theology is a form of Christian radicalism which was strongly opposed by U.S.-backed regimes during the Cold War (Sigmund, 2007). Romero's assasination is an example of how political violence takes place by stifling opposition through the killing of proponents of policies that run counter to capitalist economic interests. Much of the political violence in Central America is attributed to the long history of the United State's involvement in that region.

In many cases, political violence takes advantage of vulnerabilities in a corrupt system. Corrupt regimes must often resort to violent tactics to maintain their grip on power. In countries like Honduras, corruption at high levels of government is widespread. Its corruption is primarily attributed to the debasement of democracy that took place when U.S. intelligence produced ties with the Honduran military and elites using bases across Honduras to train former military men from Nicaragua throughout the Cold War, which ultimately produced lingering effects on the region like in 2009 when US intelligence assisted the Honduran army in a coup against President Zelaya. 
The effects of the U.S.'s engagement are still apparent through the levels of corruption and political violence in the country. An example of corruption in Honduras in a more recent context is seen in March of 2021 when Honduras's president Juan Orlando Hernandez was accused of stealing government money and taking bribes from cocaine traffickers (narcos) in a state-backed operation. Hernandez's brother, Juan Antonio Hernandez, was additionally prosecuted for conspiring to smuggle 200,000 kilograms of cocaine to the United States. Although both of the Hernandez brothers denied involvement, the court was able to provide a significant amount of evidence exposing them as key players in the drug trafficking operation (Palmer \& Semple 1). Perhaps not too surprisingly, this wasn't the first time Hernanez has been accused of corruption. In order to win re-election in 2017, President Hernandez built a relationship with drug traffickers who financially supported his campaigns in return for protecting them from getting in trouble with the law. Not only is corruption rampant at high levels of government, but it also plagues the authorities in local regions. This status quo of corruption at both the local and national level has left the country vulnerable to vast internal, violent political dissent. Following Hernandez's reelection, violent protests erupted across the country. In response, police utilized "illegal and excessive use of force" on protesters (Ernst \& Malkin 1) which left 22 people dead. People were not only angry because Hernandez cheated his way to winning re-election, but also with the fact that he additionally filled his Supreme Court with judges who worked in his favor. According to Palmer and Semple (2021), Hernandez's actions have led to a noticeable flow of Honduran migrants to the U.S. border.

Furthermore, although women are less likely to suffer from political violence than men, women are still impacted both directly in the case of women activists and politicians — or indirectly through the loss of partners and children. A direct case of political violence against 
women can be seen through the story of Berta Cáseres, a Honduran activist who was murdered in an act of political violence in 2016. Following the 2009 coup, Honduras experienced growth in environmentally harmful projects which were displacing indigenous populations from their homelands. Cáseres was involved in various land and water struggles along with Lenca indigineous communities. She led many against builders of a hydro-electric dam which when built would flood indigenous lands. In February of 2016, Cáseres was gunned down in her own home by a group of hitmen who were linked to the company building the dam (BBC, 2016). Despite repeated death threats, Cáseres continued to fight for indigenous land and water rights - which ultimately led to her murder. Overall, Cáseres' murder is an example of how political violence puts women activists at risk. Ultimately, as proposed by Menjívar (2011), women face gendered violence primarily in the forms of organized crime, interpersonal abuse, structural violence, and political violence. These variables ultimately influence their decisions to migrate to the United States. 


\section{Violence in Migrant Corridors}

The migrant trail is the most hazardous part of the migration process. Migrants are targets of great violence that is exacerbated by gender inequalities. According to Slack et al. (2016), an increase in vulnerable populations migrating through Mexico has resulted in an exponential increase in violent episodes throughout migrant journeys. Various scholars have looked at how women are more vulnerable to violence than men — specifically physical and sexual violence on migrant trails.

\section{The Journey North}

Migrants refer to the United States as el Norte (the North) which is roughly 1,800 miles from the Guatemalan border to the United States border. In order to travel safely migrants often hire coyotes (human smugglers) who make a living out of guiding undocumented migrant caravans to the United States. Being able to afford a coyote isn't easy, but it is the safest way to migrate to the United States. Prices range anywhere from 5,000 dollars to 7,000 for a packaged deal for an adult and child (Burnett 1). Many families save for months and even years to send their loved ones to the United States. Migrants and their families will often go into debt to pay a coyote in hopes that they can eventually repay the money when they work in the United States. According to Arroyo et al. (2021), Ricardo García Pérez and his wife Olga Pérez were able to raise 25,000 quetzales (3,235 US dollars) to send their daughter Santa Cristina Pérez to the United States with a coyote. They got the money to do so through loans and handing over the deeds of both their home and family farm. Santa Cristina dreamed of migrating to the United States to work and send money back to Guatemala so her year old sister, Ángel, could get surgery for the cleft palate she was born with. Unfortunately, Santa Cristina was part of a group of 19 migrants who were found dead, burnt, and with bullet wounds on an isolated path near 
Tamaulipas in Northern Mexico. It was later determined that Mexican police officers were at fault for the murders which had been a result of a deadly shootout (Sieff and Martínez, 2021). Migrants risk not only their lives, but they often risk everything they have in hopes of a better future in the United States knowing they might not even make it there.

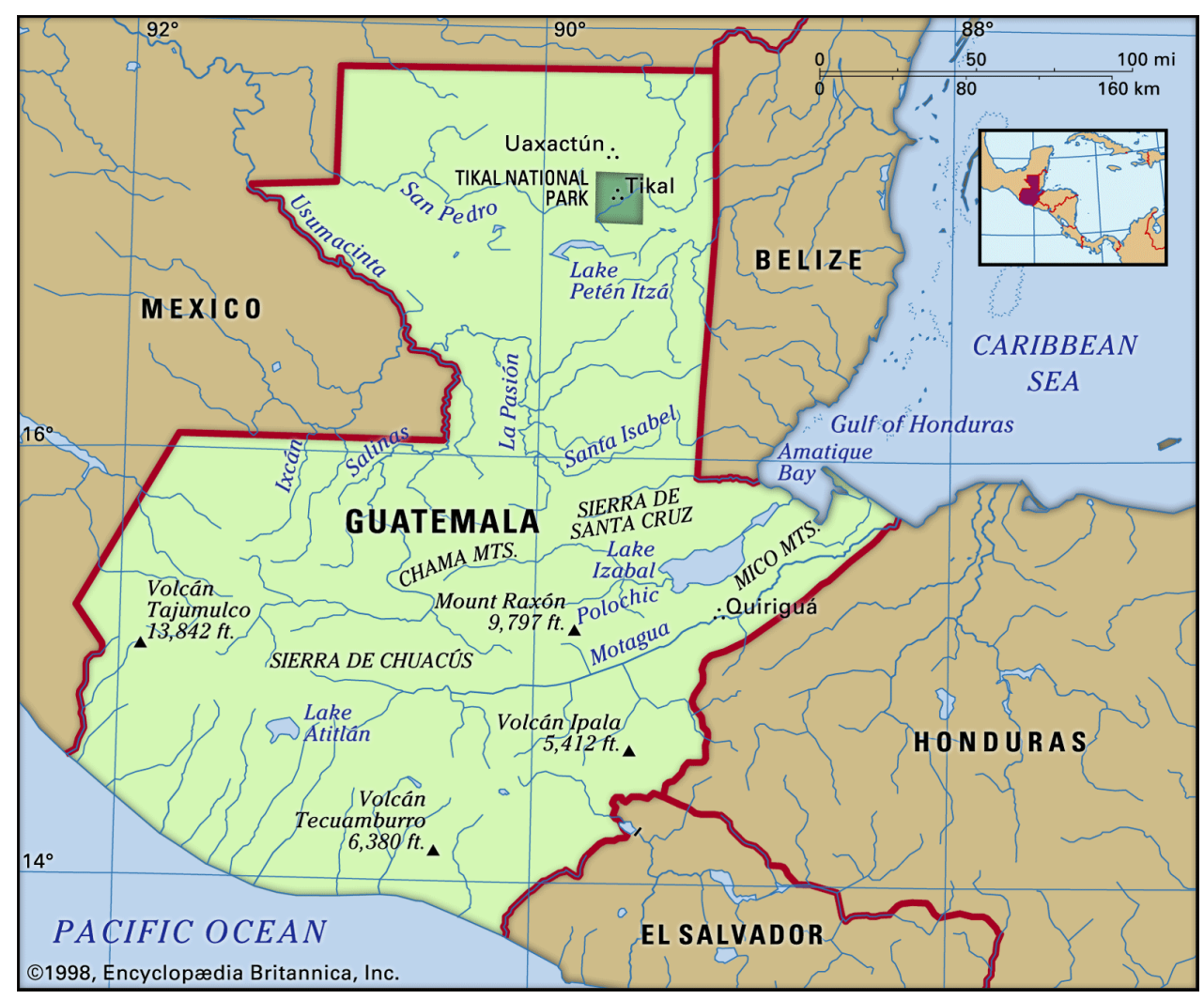

Figure 3: Map of Guatemala-Mexico border. Source: Encyclopedia Britannica

In order to get to Mexico, Central American migrants have to pass through the Guatemala-Mexico border (see Figure 3). Most pass through a place called Gracias A Dios in Guatemala which is described as a "trafficker's boomtown" (Burnett 1). The Guatemala-Mexico border is not heavily guarded, which means that the state is less likely to retain a monopoly over the use of force. Crossing the Mexican checkpoint with a coyote is relatively easy since coyotes often pay bribes to Mexican officials. Once migrants get to Mexico, they board buses that get them to Mexico City. From there, they are sent through various forms of transportation to one of 
many cities on the US-Mexico border, such as Ciudad Júarez, Mexico. From there, in order to evade US migration officers or la migra, migrants wade through the Rio Grande River, or cross the Sonoran Desert if further west, to enter the United States.

There are many factors that contribute to a migrant's vulnerability. First, throughout their journey they are often deprived of basic human necessities like food, water, and hygienic supplies. Although curtailed access to basic needs makes migrants susceptible to violence, Leyva-Flores (2019) finds that other variables such as gender and nationality are higher indicators of whether a migrant will experience violence when traveling to the United States (9). Criminal groups, as well as Mexican authorities, have a long history of exploiting migrants. Many youth and women reported being subject to extortion, sexual assault, kidnapping, forced dissapearance, and human trafficking (Stinchcomb et al. 2014). According to Schmidt (2017): "Politicians, police, gangs, cartels, and traffickers rely on the invisibility of migrants, effectively denying them protection of the law and thus making them more vulnerable to exploitation" (140). The second they leave their countries of origin as undocumented migrants, their moves become undetected as they enter a "shadowy world" (Gomez 53).

The Zetas are one of Mexico's most dangerous criminal groups who often work in conjunction with corrupt Mexican officials. In January of 2021, 19 charred corpses of Central American migrants, mainly from Guatemala, were found in two trucks on a rural road between Tamaulipas and Nuevo León in Northeastern Mexico. One of the dead was 20-year old Santa Cristina Pérez mentioned earlier. Although 12 Mexican officers were detained for the murders, it is unclear whether they will ever be held responsible. The attack occurred because officers mistook the group of migrants for a group of criminals and shot at them. After realizing their mistake, they collected the shell casings from the two trucks and drove off leaving the migrants 
there to die (Arroyo et al. 1). According to Arroyo et al. (2021) the rural roads around Tamaulipas are known as a "graveyard for migrants"(1) an area that many locals try to avoid. The largest massacre in that area occured in 2010, when 72 South and Central American migrants were found in hidden graves. Overall, the attacks in Tamaulipas are one of the many examples of how Mexican police and criminals take advantage of migrants' vulnerability. As the father of Santa Cristina Pérez, who was killed in the 2021 attack, said:

They invested and risked everything in search of a better life, traveling to the United States without documents that would allow them to work. But they were found shot dead, and their bodies charred in the north of Mexico (Arroyo et al.1).

Physical violence on migrant trails isn’t always tied to drug cartels. Many local gangs take advantage of migrant's vulnerability to make money by robbing or overcharging them, sometimes even threatening to turn them in to the authorities for detention. A woman interviewed by Shetty (2014) talked about traveling on top of a boxcar with her two kids. When the train stopped, three gang members hopped into her boxcar threatening to throw her kids off the top if she didn't pay them. "They said they would hold us until we could call a relative to arrange to pay. If you couldn't pay, they would throw you off the roof" (Shetty 1). Others impersonate police to take advantage of them. The same migrant said she was confronted by three "agents" who threatened to turn her in if she didn't pay them 500 pesos (roughly 25 US dollars). Sexual violence is also common across migrant trails. Although the sexual exploitation of males does occur, research shows that it occurs at much lower rates than to women (Gomez 53). Migrant women are raped by guides, fellow migrants, criminals, or governmental officials (Goldberg 2014). However, Leyva-Flores (2019) argues that some women engage in sexual acts 
as a "tool necessary to facilitate their passage and protect themselves from greater harm" (9). As one Guatemalan migrant woman admitted: "The advantage of being a woman is that men will help you just to have sex with you. Just think of it as paying for protection with [your] body" (Leyva-Flores 9).

Sexual assault is sometimes accompanied by kidnapping. Lupita, a 19 year old woman from Honduras left her country to escape abuse from her father (Schmidt 148). Two days after leaving Honduras she was robbed of her phone and all the money she had, sustaining a severe foot injury in the process. She then walked for 6 hours searching for help and came across a man who offered to take her to a pharmacy to help her. The man offered her to stay at his hotel room, and having nowhere else to stay, Lupita accepted his offer. Upon walking into the hotel room a gun was pointed at her head and four men told her that if she didn't comply, they would kill her. Lupita was repeatedly beaten and raped by the men for four days, but on the fourth day she escaped while they were sleeping. Lupita was extremely humiliated and blamed herself for what happened, but that didn't stop her from continuing towards the United States. As she said: "I am going to keep going and nothing will stop me. I have to continue because I have to, I have to fight for my family. I have to fight for my mom and siblings" (Schmidt 148). As women are trying to escape violence from their countries of origin they risk experiencing sexual and physical violence in their pursuit to live a better life in the United States.

Human trafficking is another element of violence that commonly occurs on migrant trails across Mexico. Gomez (2012) finds that most of the Central American women who are trafficking victims were trafficked for purposes of sexual exploitation. According to a study conducted by CEIDA (Centro de Estudios y de Investigación en Desarollo y Asistencia Social), sex trafficking victims in Mexico are predominantely Central American migrants from 
Guatemala, El Salvador, Honduras, and Nicaragua (Gomez). Human trafficking rings seek potential victims in places where migrants congregate. Migrant women are particularly vulnerable to human trafficking because their families have no way of tracing them, thus making it easier for their captors to commit crimes undetected. When trafficked, women are forced into lives of both sexual and physical labor. If not sexually exploited, they are forced to beg on the streets, bringing back money to their captors. Once trafficked it is extremely difficult for women to leave, as their captors often threaten them with violence. Overall, as Gomez notes: "women and girls headed north find themselves compromised and exploited" (55). Traffickers are ultimately able to profit off of migrants by taking advantage of their vulnerability and disorientation.

Violence against migrant women, especially sexual crimes, often remain unreported since women fear deportation and don't trust government officials. Women often unknowingly confide in individuals who take advantage of their vulnerability. Even if crimes are reported, it is rare for perpetrators to be prosecuted. Corcoran (2014) presents data showing that the Mexican government did not make a single conviction involving migrant rape cases from 2008 to 2011 (1). Schmidt argues: "As all migrants in transit in Mexico are especially vulnerable to violence, female migrants are the most vulnerable among the vulnerable" (Schmidt 143). Such violence is so prevalent that most migrants accept that as part of the price they are willing to pay to come to the United States.

While all migrant women are highly vulnerable to violence on the trail, indigenous women are particularly exposed to racial violence. Astles (2016) finds that there are racial hierarchies amongst migrants which impacts the way some are treated and perceived. Migrants are often treated based on their physical characteristics including skin color, hair color, and eye 
color. Morley (2021) finds that migrants who have darker skin stand out to officials and are more likely to experience abuse. One migrant was quoted saying: "The Mexican people insult us on the street, try to avoid getting close or touching us, and cover their noses" (Morley 42). Overall, the intersectionality of race and migration can be seen through the ways that migrants are disproportionately treated by both their nationality and race as they migrate through Mexico. This issue of racial marginalization is part of the larger scope issue of colorism in Mexico. As presented by both research and personal interviews, when migrating from Central America to the United States, migrants pass through Mexico where they face harrowing violence. As one migrant admitted, "In spite of all the hardships we left, the real nightmare is the journey through Mexico" (Shetty 1). Although migrant women are escaping the violence in their countries of origin, they face both physical and sexual violence. Gender and racial inequalities heighten this violence. In many cases, gangs, cartels, corrupt police officers, male travel companions, and traffickers take advantage of their vulnerability. 


\section{Violence at the United States/ Mexico Border}

Crossing the United States-Mexico border is one of the most dangerous parts of migrating to the United States. The most common ways that migrants die at the border are heat stroke, dehydration, and direct violence (Holmes). This is part of the risk that many are willing to take, as a migrant interviewed by Holmes (2013) said: "border experience is a principal experience of sufrimiento (suffering)" (30). As migrants arrive at the border, they have to decide whether they want to find a way to cross illegally, or choose to seek asylum. According to The US Refugee Act of 1980, "foreign nationals are allowed to claim asylum if they have a well-founded fear of persecution for reasons of race, religion, nationality, political opinion, or membership in a particular social group" (DWB 25). Although it is both Mexico and the United State's legal responsibility to provide asylum seekers with security, this isn't always the case. Restrictive policies, particularly those put into place by the Trump administration, have restricted access to asylum in the United States, further exposing migrants to violence and suffering.

\section{Seeking Asylum}

There has been a large rise of asylum seekers at the United States/Mexico border due to the humanitarian crises in Mexico, Central, and South America. In 2018, there were 161,000 asylum claims with another 800,000 asylum cases waiting to be reviewed, with an average waiting time of 700 days (DWB 25). According to a report published in 2019 by Doctors Without Borders (DWB), those who are seeking asylum and safety are often treated like criminals. Despite their duty to protect asylum seekers the United States and Mexico have implemented measures restricting access to asylum in the United States particularly due to the actions of the Trump administration. As the report argues: "The complex web of policies implemented by the Trump administration to deal with the situation deliberately intends to 
dismantle the system to protect asylum seekers" (24). Rather than confronting the various push factors that are contributing to mass migrations and the humanitarian crises, the United States has been known for returning Central Americans seeking refugee status to Mexico, where they must wait for their claims to be processed in the midst of border violence. According to DWB, as of November of 2019, there were approximately 21,398 asylum seekers on waiting lists in Mexican border cities (26). By sending migrants back to Mexico, the United States is able to comply with the 1967 Refugee Convention protocol which includes the principle of non-refoulement, which prevents countries from sending back asylum seekers to their countries of origin where they may face life-threatening challenges (DWB 25).

One way in which the Trump administration has restricted access to asylum in the United States can be seen in 2018, when the Attorney General's Office began to exclude domestic violence and gang violence as grounds for seeking asylum, stating that they were "private criminal activity" (DWB 26). Although the policy has been struck down by US courts, there are other barriers that the government has put up making it extremely difficult for asylum seekers to be granted refuge (DWB 26). Furthermore, in 2018 the US government proclaimed that asylum seekers must use an official port of entry in order to seek asylum. Under those grounds, those who had previously crossed the border "unlawfully" would be unable to file asylum claims even though under US law, anybody has the right to seek asylum.

The Mexican border towns (see Figure 4) where most asylum seekers are forced to stay are extremely dangerous. Ciudad Juárez, an important border town in Mexico, is notorious as one of the most dangerous cities in North America with 1,646 people murdered in 2020 (Resendiz 1). Júarez is a common port of entry to El Paso, Texas, where drug and gang violence is prevalent posing a large threat to the safety of migrants. If migrant's claims are rejected, they 
are sent back to their countries of origin under the Asylum Corporations Agreements. Under these terms, vulnerable populations are sent back to countries where they will continue to experience violence. The US and Mexican governments have failed to ensure that asylum seekers receive protection, resulting in migrants thrust into situations where they experience further violence.

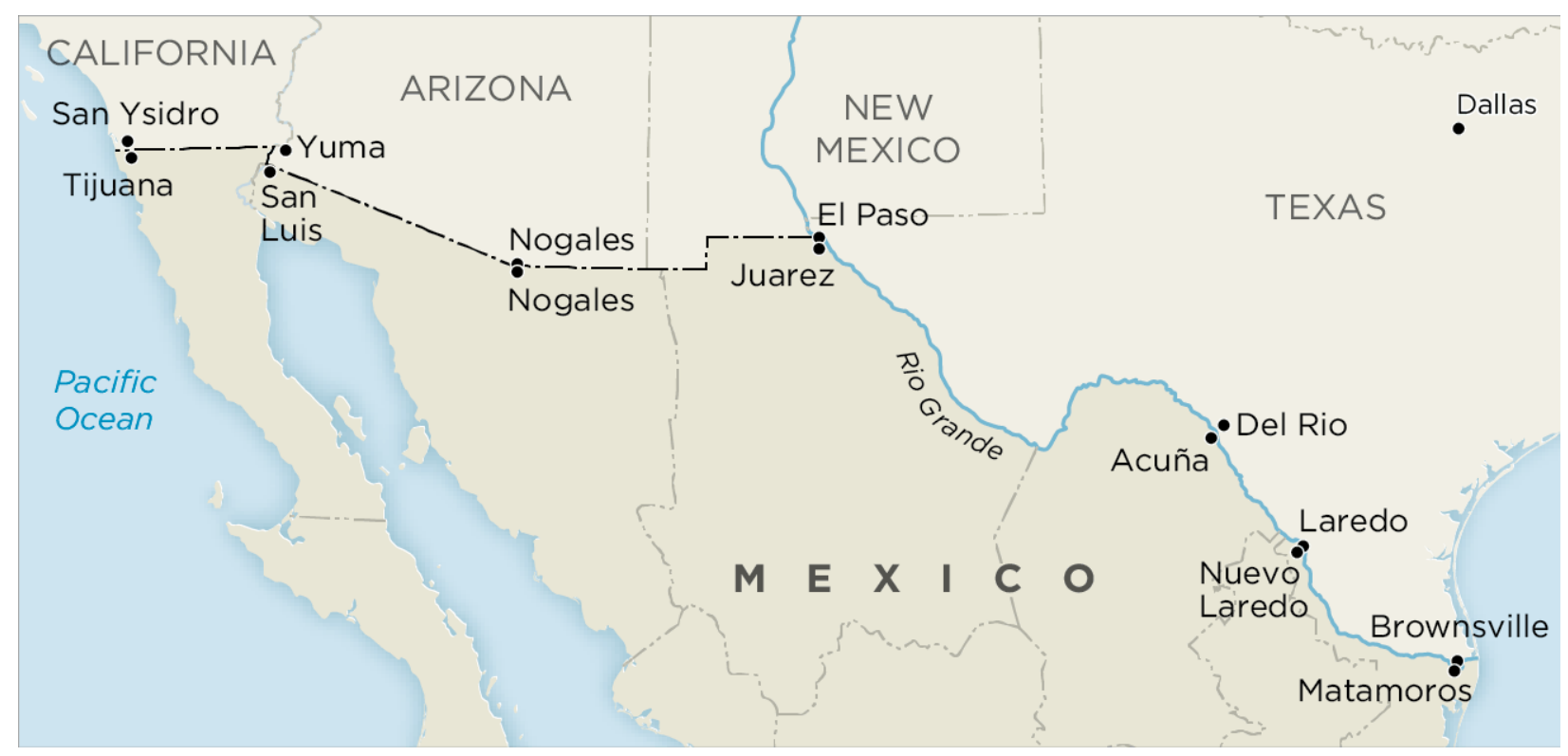

Figure 4: Map of prominent United States/Mexico border cities. Source: The Dallas Morning News

\section{Immigrant Detention Facilities}

Migrants who are seeking asylum are often sent to detention centers in Mexico or the United States (see Figure 5) where they experience inhumane conditions, often separated from their families and travel partners. At these facilities they are deprived of physical and mental health care after suffering extortion, near-death experiences, assault, kidnapping, and sexual assault during their migrant journey (DWB 10). The violence that migrants experience in their countries of origin, as well as throughout the migrant journey, leaves many of them with severe PTSD, trauma, severe depression, and anxiety (DBW 21) that they must cope without support in 
these facilities. As DWB says: "What they are told before the journey is nothing compared to what they suffer along the way" (20). Among the women surveyed by DWB (2019) 37 percent (17/46) admitted to experiencing suicidal thoughts at immigrant detention centers. These facilities are run by US Immigration and Customs Enforcement (ICE) agents who have a track record of neglecting migrants, particularly children and youth who are already vulnerable since many are separated from their families.

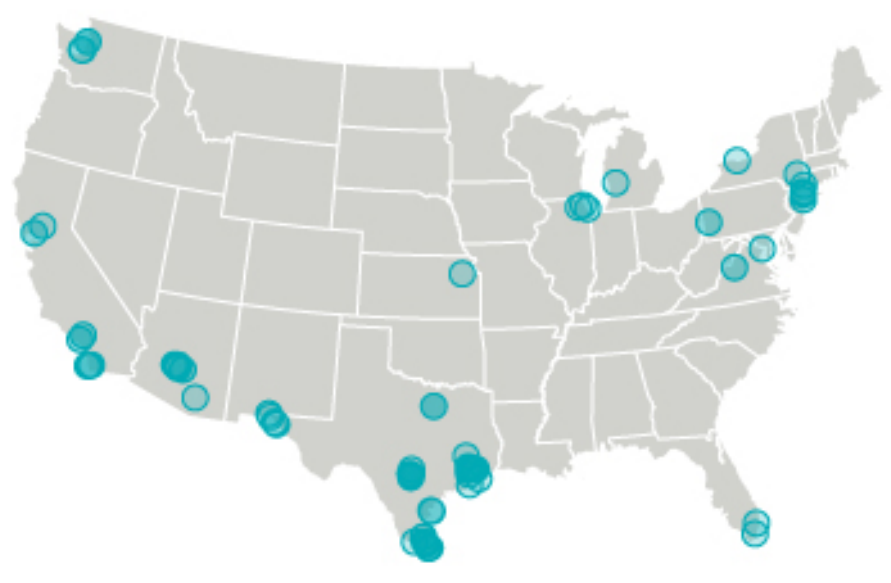

Figure 5: Map of immigrant detention facilities in the US. Source: Refugeeswelcomehome.org Aside from state officials, no one is allowed in migrant detention facilities. The only way to truly understand the conditions inside these centers is to hear the stories from the migrants themselves. Humanitarian groups like the Detention Watch Network dedicate themselves to documenting the stories of migrants who are neglected at the hands of US border agents. This group is made up of a network of advocates and activists who dedicate themselves to ensuring that the dignity and rights of migrants are respected. The group conducted a series of audio interviews with migrants who were held in various detention centers across the United States in order to expose the gruesome conditions that migrants face. Lisette Piñeda and her 11-year old 
son Alexis fled Honduras after Alexis's best friend was murdered. Lissette and her son were sent to Karnes Family Detention Center in Texas where they spent nine months locked up, facing inhumane conditions. As Lissette said in her interview: "To think the boy (Alexis) is barely 11 years old and comes here traumatized, and he's going to leave traumatized from being locked up" (Detention Watch Network). Another man interviewed named Elder Virgilio Gómez-López and his two sons fled Guatemala with his two sons after he got shot in the stomach. Elder, who had a colonoscopy bag, was held at Eloy Detention Center in Arizona for six months. There, he was denied proper medical care for his medical condition. When asking for better treatment for his medical problems Elroy recalls being told that "This is not a hotel for you to be asking for pleasures" (Detention Watch Network). Stories like those of Lisette and her son, as well as Elder and his sons, are the results of the United State's failure to protect the wellbeing of asylum seekers.

\section{US Immigration Politics}

Schmidt (2017) argues that increased border control at the US/Mexico border has further exposed migrants to violence "at the hands of organized crime, smugglers, and corrupt Mexican officials (Schmidt 142). A report consisting of 480 interviews and testimonies of Central American migrants and asylum seekers by Doctors Without Borders (2019) exposes how harsh migration policies adopted by the United States and Mexico have exacerbated the dangers that migrants face. The surge in migrants through the past two decades has had a large influence on the politics of migration to the US. Despite their duty and legal obligations to protect those seeking protection, Mexico and United States governments have collaborated to increase the risks faced by migrants in order to discourage illegal entries to the US. A policy of "prevention through deterrence" followed by the U.S. migration authorities, has "deliberately channeled the 
migrant stream toward the most dangerous places (such as desolate, and therefore deadly, desert zones) on the U.S-Mexico border" (Speed 12). The United States has particularly placed great pressure on the deterrence of migrants from Mexico and Central America. In 2014 Mexico announced a plan called Plan Frontera Sur (Operation Southern Border) which according to Schmidt (2017) aimed to "deter migrants from continuing their journey" (Schmidt 141). Although Plan Frontera Sur slowed migrant flows from Central America to the United States, it has ultimately rerouted migrants to areas that were much more remote and dangerous in attempts to avoid interception by ICE. For example, it was found that after 2015 more migrants were crossing the United States border through the Arizona desert, which is much more dangerous than the Texas border, where they used to cross (Schmidt). "No matter how much the U.S. government stresses that undocumented immigrants will be deported, these individuals who fear for their lives will not heed the warning and will continue to come" (Folkerts et al. 1).

The crisis at the border only got worse in 2018 when US Attorney General Jeff Sessions announced a "zero tolerance" policy which prohibits illegal entry to migrants, threatening them with prosecution and separation of their families. This policy resulted in the separation of thousands of children from their families. Although President Trump, after receiving a lot of political pressure, issued an executive order stopping these separations, they continued . In October of 2019, the American Civil Liberties Union found that roughly 5,460 children had been separated from their families since 2017 (DWB 24). One report finds that migrant children were held in frigid holding cells the children described as hieleras (freezers), with limited access to food and medical care (DWB 25). Ultimately, an increase in security and changes in U.S. immigration policies have put migrants in positions where they are forced to encounter even more dangerous, inhumane conditions. 


\section{Covid-19 Pandemic}

The Covid-19 pandemic has added an extra layer of violence and suffering to the lives of asylum seekers at the United States border. When President Joe Biden was elected, his administration promised to take steps to reverse the damage done by the previous Trump administration regarding the treatment of asylum seekers at the United States/Mexico border. Towards the beginning of the Covid-19 pandemic in March of 2020, the Center for Disease Control was pressured by the Trump administration to violate US refugee law through Title 42 as a way to mitigate the spread of coronavirus. As a result, asylum seekers have been rejected at the border without the opportunity to apply for asylum. Following his election, President Biden has been able to make some progress towards helping refugees, but he hasn't upheld his promise to reverse the damage caused to the government's misuse of public health authority to block asylum seekers from entering the United States southern border throughout the pandemic. According to Human Rights First (HRF) (2021), such policies have failed to protect migrants and asylum seekers and instead of preventing deaths and the spread of disease, such policies are forcing asylum seekers into violent situations in violation of US refugee laws and treaties. Human Rights First tracked down a total of 492 violent attacks and kidnappings that occured against refugees who had been denied asylum, this in the time since the inauguration of the Biden administration (HRF 1). According to HRF, the Biden administration has blocked asylum seeking families from all Central American countries, but mainly from Honduras, El Salvador, and Guatemala. The administration has justified such actions using Title 42 arguing they are trying to "buy time" to implement a comprehensive process for asylum seekers in order to undo the damage that the Trump administration has caused, as well as to slow the spread of the coronavirus (HRF 1). Ultimately, both the Trump and Biden administrations have denied refuge 
to migrants who are not only escaping violence at home, but are exposed to further violence due to the heightened militarization of the United States border.

\section{Gendered Violence at the Border}

Women are further confronted with gendered violence when they reach the United States/Mexico border. As Vera (2013) finds, the abuse of migrant women is normalized at the US/Mexico border particularly at the hands of US border agents. Border agents are known for abusing their power, sometimes accepting sexual favors from migrant women. Vera argues that the abuse of women by immigration agents is attributed to militarization at the border where human rights violations are used as a form to exert power (6). Many women see the sexual violence they experience as a price they are willing to pay to gain entry to the United States. They also see the abuse as "expected" and as "usual male conduct" due to the environments they are used to experiencing in their countries of origin (Vera 6). In 1993 a woman named Juanita Gómez was raped along the US/Mexico border by an immigration agent named Larry Sanders. Agent Sanders had allegedly told Juanita that if she had sex with him, he wouldn't deport her. When she rejected him, he coerced her into his truck and drove away and raped her in a parking lot. Although Juanita reported the rape, the police did not believe her, as they believed she was a prostitute. Border agents often get away with such abuse due to the unequal racial and gender power relations between them and their victims. As Vera argues, Juanita's story is an example of how masculinity and militarism result in violence (6).

Women are also confronted with gendered violence at migrant detention centers. In September of 2020, a whistleblower in Georgia reported that doctors in migrant detention centers were performing nonconsensual hysterectomies on migrant women. The whistleblower, who was later identified as nurse Dawn Wooten, told that Spanish-speaking migrants were receiving 
hysterectomies without fully understanding the medical procedure, as there was a language barrier between them and the health care providers at the ICE facilities. One migrant from the Georgia facility said: "it's an experimental concentration camp... it was like they're experimenting on our bodies" (BBC 2020). Although investigations on the hysterectomies are still ongoing, ICE has failed to take accountability for the allegations. Overall, migrant women have been silenced from the sexual abuse they have faced at the hands of border agents and migrant detention center doctors. The United States government has failed to provide welfare for asylum seekers exposing them to further violence through human rights violations. 


\section{Mitigation:}

\section{Providing Safety to Central American Women}

In the face of the many dangers that make the journey North more difficult, women must find ways to protect themselves either using their own resources or, in many cases, relying on external entities. These external efforts, typically private efforts, are paramount to mitigating violence on migrant trails, particularly in Mexico. More specifically, religious groups, humanitarian groups, and civil rights organizations provide shelters which operate along these routes. These privately-run sanctuaries provide migrants amenities like food, water, healthcare, toiletries, and legal advice (Schmidt 144). Doctors Without Borders (DWB) is one of these groups. As professed in their mission statement, DWB works to "provide lifesaving medical care to those most in need" (DWB). According to a report published by DWB in 2019, migrants come to shelters with a variety of physical and psychological problems. The Central American migrants and refugees they treat suffer severe trauma from exposure to physical, sexual, and racial violence, both in their countries of origin and throughout their migrant journeys (6). DWB aims to provide care to victims of chronic violence. Ensuring that migrants get the healthcare they need greatly improves their likelihood of survival as they migrate to the United States.

Migrant shelters not only house migrants, but also assist in the creation of migrant networks. Women who stay at migrant shelters often form migrant networks with other women. Schmidt (2017) argues that a migrant's social ties, both in their countries of origin and during their migrant journeys, provide a valuable source of social capital to migrant women (152). Social capital fosters migrant networks that help women throughout their migratory experiences, including their crossing into the United States. As Schmidt finds, social capital aids migrant women by providing them with "food transportation, shelter, and potential jobs" (152). These 
social ties provide resources which, as Schmidt points out, can be ultimately transformed into the acquisition of material capital (152). Research conducted by Schmidt on migrant women in Mexican migrant shelters indicates that one of the most notable outcomes of migrant networks is that they provide security to migrant women as they travel North. Schmidt's work finds that dinamicas (dynamics) emerge amongst groups of migrant women who travel alone who congregate, sharing and expressing their fears and experiences. Migrant networks help migrant women bond over shared experiences, some even choosing to continue their travels together. Out of the women that Schmidt interviewed, 38 percent decided to continue their migrant journeys with other women they met at migrant shelters (152). Schmidt's study also found that even after leaving migrant shelters women who were separated from one another would still stay in contact with one another through social media applications like WhatsApp and Facebook (153). As Schmidt's study concludes, migrant networks establish long-term relationships between migrant women providing them with security as they migrate and enter the United States.

Other non-profit organizations aim to help migrants and refugees through community based direct action. Border Angels, a nonprofit organization based in San Diego, California advocates for the rights of migrants and refugees at the United States/Mexico border through community based reform where they aim to educate and assist communities on both sides of the border (Border Angels). Through their "water drop" program, Border Angel volunteers have left thousands of gallons of water in the Southern California desert where migrants often travel through. According to their website, the organization placed over 1,200 gallons of water on desert routes in 2020 as well as picked up trash. Another program the organization puts on is called "The Caravan of Love" where they collect and distribute donations of food, clothing, toiletries and other basic necessities for migrant shelters. 
Furthermore, certain organizations work towards ending violence in Central America. MOMUCLAA, a non-governmental organization in Honduras created by women in 1992 works to combat femicides in Central America. This organization works to aid women who suffer from domestic violence by providing them with emotional support and helping them find psychological help. MOMUCLAA's director Melania Reyes has risked her life on several occasions to help girls who have been as young as 11 years old. On several occasions she has rescued women from violent situations of domestic abuse. Although MOMUCLAA provides victims with support, its efforts only provide short-term solutions as femicides are growing exponentially across the region (VICE). As Melania notes in an interview: "It's hard when there is no opportunity to move forward. No chance to work... No Security, no health programs, it's a complete mess (VICE). Non-profit organizations like Doctors Without Borders, Border Angels and non-governmental organizations like Momuclaa do a significant amount of work to help both educate communities on the humanitarian crisis as well as help migrants and refugees with the basic necessities they need to survive. Despite their best efforts, nonprofits only remedy violence in the short term instead of addressing its origins. It is up to governments in Central America, Mexico, and the United States to address the root causes of violence which ultimately result in mass migrations from Central America.

The United States has its shortcomings in adequately addressing root causes of migration. In June of 2021, United States Vice President Kamala Harris spoke at a conference with Guatemalan President Alejandro Giammattei warning potential migrants to not come to the US illegally. In attempts to stunt the violence occuring at the US/Mexico border, Harris addressed Guatemalans saying: "Do not come. The United States will continue to enforce our laws and secure our borders... If you come to our border, you will be turned back "(BBC 2021). While it 
may seem that if Harris' remarks were put into action this would slow down the influx of migrants by discouraging immigrants to cross the border, the words of politicians have little to no effect on immigrants crossing the border, that is if these words are not backed up by robust immigration policy. In order to truly address the high rates of migration to the United States it is critical for federal governments to tackle the root causes of violence in Central America.

The federal governments in the U.S. and Mexico could do a lot of things to prevent violence against migrant women. As Ávalos (2016) argues, Central America’s failure to address women's issues is holding the region back in terms of its development (1). There are several ways that governments could show success in providing migrants along trails with the proper resources. Some examples include offering better training for security forces and granting funding to agencies and units that aim to assist victims. As observed through nonprofit organizations and non governmental agencies, these only provide short-term solutions to migrants who come from countries in Central America with deeply rooted, systemic problems. Although it is ultimately critical for governments to promote a more stable, egalitarian functioning democracy in Central America, this goal, if approached from the wrong direction, can be retroactive to protecting migrant women and their livelihood. Thus, it is important for Central American countries to place gender-related violence at the front and center of immigration policy and ensure it stands as a major consideration when making changes to that policy. This would be a somewhat straightforward proposition if it were not for violence against women in this region being such a multilayered issue. As argued through Menjívar's (2011) framework, gendered violence in Central America is attributed to a multifaceted issue surrounding organized crime, interpersonal abuse, structural violence, and political violence. Correspondingly, to address violence against women amidst all these factors would require 
widespread cooperation at all levels of government — local, state , and federal — something which for reasons of courrpution and the disarray formed by political violence remains nearly impossible.

Despite this gargantuan task, Scholars like López et al. (2021), Ávalos (2016), and Abt and Winship (2016) have proposed a broad yet promising method of solving this humanitarian crisis in Central America. Abt and Winship argue that to properly address the various facets of violence, governmental and nongovernmental players must focus on long-term solutions that concentrate on reducing violence across the region. This begins with examining key set-backs in the region's development. These setbacks include: chronic poverty, gaps in education, and access to welfare (Abt \& Winship). Furthermore, to specifically mitigate the violence that Central American women experience both in their countries of origin and through migratory processes, long-term structural solutions include empowering women as agents of change (Ávalos). If effective mechanisms aren't put into place, Central Americans, women in particular will continue to face lives of violence in their countries of origin, with many likely to expose themselves to further violence in the migratory process.

Violence in Central America disproportionately influences the lives of Central American women due to systemic factors of organized crime, interpersonal abuse, structural violence, and political violence. In order to specifically address gendered violence in Central America, it is critical for policymakers to acknowledge the region's setbacks in providing women with sustainable futures. A major step in addressing Central America's setbacks in development is to empower women as agents of change. According to The World Bank (2016), not only does empowerment foster women's participation in Central America, but it fosters economic growth and development which in turn helps the region have higher economic growth and 
macroeconomic stability (16). As Ávalos (2016) further argues, women's empowerment is not simply ensuring basic human rights for women, but rather providing both regulatory and legal tools to ensure that women's needs are addressed (Ávalos 1). The World Bank (2016) published a report suggesting ways to achieve better outcomes for women through the promotion of both economic and social inclusion such as access to education, labor participation, and political participation (13).

The World Bank (2016) reports that education plays a large role in mitigating the violence that occurs in both Central America and throughout the migration process. According to the report, education helps protect women from violence (World Bank 40). A study conducted in Honduras found that 6.6 percent of women in tertiary education reported experiencing domestic violence at home, meanwhile 11 percent of women with no education reported experiencing the same violence (World Bank 40). Similarly, a study in Panama found that 14.1 percent of women with no education reported experiencing violence while 4.8 percent of women with a tertiary education admitted to experiencing violence (World Bank 40). Bridging the education gap is a critical step in mitigating violence across Central America.

Another step towards women's empowerment includes increasing women's labor participation. According to The World Bank (2016), negative labor market outcomes for women contribute to the persistence of poverty and gender inequalities which are some of the leading causes of mass migrations (64). Women workforce participation across Central America contributes to economic growth and development of the region. This begins with integrating women into male-dominated industries. Women Investing in Growth and Security (WINGS) is a government funded organization that provides funding for economic development projects that employ women. WINGS has funded projects ranging from helping female flower farmers to 
boosting women into male-dominated workforces like ranching, construction, and other vocational industries (Inter-American Foundation). In Honduras, WINGS invested in helping indigenous women learn sustainable farming methods and learn how to market their products (Inter-American Foundation). In El Salvador, WINGS helped women learn savings and loan management (Inter-American Foundation). Similarly in another community-based development approach in Nicaragua in 2007 explored by the World Bank (2016), women built cobblestone roads which was a job that was traditionally considered "men's work" (The World Bank 70). As The World Bank discusses, through this project women developed skills which had "profound psychological and human development effects"(The World Bank 70) which are beneficial towards addressing poverty and gender gaps.

Another major step towards women's empowerment explored by The World Bank (2016) includes heightening women's political participation. Central America has failed to provide women with social organizations which allow for women to exercise autonomy. Facilitating women's political participation is critical to alleviate the various facets of gendered violence described in Menjívar's (2011) framework. Placing women in public decision-making spaces allows for them to exercise their rights, making decisions on gendered topics that are often ignored. As The World Bank argues, women are more likely to vote for female legislators who typically spend more on social and welfare services (27). Additionally, women legislators have a large impact on policies which address topics that influence the livelihoods of women like contraceptives access (27). According to the 2021 Commission on the Status of Women's report, having women in positions of power creates a "substantive representation that reflects their different problems and interests in laws, policies and budget"(14). Due to the instances of 
gender-based that women in Central America are facing, it is urgent to ensure that women are given the right to exercise their rights to achieve their greatest potential.

Overall, as The World Bank (2016) argues, increasing women's empowerment through higher education, labor participation, and political participation ultimately plays a role in alleviating the violence that women experience in Central America. These steps contribute to addressing Menjívar's framework of the systemic drivers of gender-based violence. It is critical for Central America, Mexico, and the United States to focus on the various facets of violence in Central America in order to create changes to address the conditions that are leading people to migrate. More change is needed beyond education, job creation, and political participation, however in order to make lasting investments in women, it is also critical to address deeply-rooted, structural issues that are hindering Central America's progress in creating a just, equitable, and prosperous society. 


\section{Conclusion}

The humanitarian crisis in Central America has grown exponentially in the past few decades - driving large groups of migrants to the United States. Emigration from Central America is predominantly driven by deteriorating socioeconomic conditions and generalized community-level violence. Much of the violence in Central America occurs in its northernmost region known as the Northern Triangle, which is known as one of the most dangerous places in the world outside of warzones (Wilson Center). The leading causes of migration from the Northern Triangle include: food insecurity, lack of economic opportunities, and violence (FAO). Many of the Central American migrants are women who face harrowing violence in their home countries, predominantly in the forms of organized crime, interpersonal abuse, structural violence, and political violence. Migration is a response to adversity and violent obstacles, thus, due to the conditions they face in their home countries, migrants feel like they have no other choice but to migrate elsewhere to provide better lives for themselves and their families.

To get to the United States, migrants pass through Mexico where they are confronted with greater violence on migrant trails at the hands of traffickers, gang members, travel companions, and state officials who take advantage of their vulnerability. Migrant women face the risks of physical and sexual violence, leaving many with severe and lasting psychological trauma, depression, PTSD, and anxiety. As migrants arrive at the United States border, they are confronted with further violence, particularly from border agents who take advantage of the imbalance in power. Women face with both physical and sexual violence as they seek asylum, often times being coerced by border officials. Seeking asylum at the border has been especially dangerous due to policies put in place by the U.S. and Mexican governments-particularly the Trump administration — which have failed to ensure that asylum seekers receive protection. 
Rather than putting measures in place that prevent the flow of migrants to the United States, it is critical for states to focus on creating systemic changes in Central American countries of origin to address the issues that are leading women to migrate from Central America in the first place. As Dyck (2005) argues, "We need [to pay] close attention to the space of everyday life to keep women visible in rapidly changing world conditions, where their activities tend to slip into the shadows of dominant models in the literature" (Dyck 234). Empowering women as agents of change is a critical step in the process of reducing violence in Central America. Focusing on empowering women through access to education, labor participation, and political participation in Central America will ultimately help overpower the violent forces that had once seemed to overpower them. 


\section{Works Cited:}

Abt, Thomas, and Christopher Winship. "What Works in Reducing Community Violence.” Jan. 2016, www.eccnetwork.net/resources/what-works-reducing-community-violence.

Agnew, Heather Robin. "Reframing 'Femicide': Making Room for the Balloon Effect of Drug War Violence in Studying Female Homicides in Mexico and Central America.” Territory, Politics, Governance, vol. 3, no. 4, 2015, pp. 428-445.

Arroyo, Lorena, et al. "The Tamaulipas Massacre: How the American Dream Dies in Mexico.” EL PAÍS, 22 Feb. 2021, english.elpais.com/usa/2021-02-22/the-tamaulipas-massacre-how-the-american-dream-di es-in-mexico.html.

Astles, Jacinta. “Intersecting Discriminations: Migrants Facing Racism.” IOM UN Migration Regional Office for Central America, North America and the Caribbean, 2016, rosanjose.iom.int/SITE/en/blog/intersecting-discriminations-migrants-facing-racism.

Ávalos, Carolina. “Central America Won't Get Better Until Women's Issues Become a Priority." Americas Quarterly, 2016, www.americasquarterly.org/fulltextarticle/central-america-wont-get-better-until-womensissues-become-a-priority/.

BBC. "ICE Whistleblower: Nurse Alleges 'Hysterectomies on Immigrant Women in US'.” 15 Sept. 2020, ICE whistleblower: Nurse alleges 'hysterectomies on immigrant women in US'.

BBC. "Kamala Harris Tells Guatemala Migrants: 'Do Not Come to US'." BBC News, BBC, 8 June 2021, www.bbc.com/news/world-us-canada-57387350. 
BBC. "Berta Caceres: Murdered Honduran Activist Buried.” BBC News, BBC, 5 Mar. 2016, www.bbc.com/news/world-latin-america-35737995.

Bachmann-Medick, Doris, and Kugele, Jens. Migration : Changing Concepts, Critical Approaches. De Gruyter, 2018.

Border Angles. 2021, www.borderangels.org/caravan-of-love.html.

Bozmoski, María Fernanda. “The Northern Triangle: The World's Epicenter for Gender-Based Violence.” Atlantic Council, 4 Mar. 2021, www.atlanticcouncil.org/blogs/new-atlanticist/the-northern-triangle-the-worlds-epicenterfor-gender-based-violence/.

Burnett, John. "Coyotes' Boomtown: Picking Up The Migrant Trail On The Way To The U.S.-Mexico Border.” NPR, NPR, 8 Apr. 2019, www.npr.org/2019/04/08/710348088/coyotes-boomtown-picking-up-the-migrant-trail-on -the-way-to-the-u-s-mexico-borde.

Corcoran, P. OAS Report Highlights Vulnerability of Migrants in Mexico. 2014 (http://www. insightcrime.org/news-analysis/oas-critiques-vulnerability-of-migrants-in-mexico).

Cruz, José M. "The Root Causes of the Central American Crisis." Current History, vol. 114, no. 769, 02, 2015, pp. 43-48.

Detention Watch Network. Detention Watch Network, www.detentionwatchnetwork.org/.

Doctors Without Borders. "The Humanitarian Crisis for Migrants and Asylum Seekers Trapped Between The United States, Mexico, and The Northern Triangle of Central America." 2019, www.doctorswithoutborders.org/sites/default/files/documents/Doctors Without Borders_No Way Out Report.pdf. 
Dyck, I. 2005. Feminist geography, the 'everyday', and local-global relations: hidden spaces of placemaking. The Canadian Geographer/Ee Géographe canadien 49(3): 233-243.

FAO Regional Office for Latin America and the Caribbean "Atlas of Migration: the Majority of Migrants from Central America Come from Rural Areas.’'12 Dec. 2018, www.fao.org/americas/noticias/ver/en/c/1174658/.

Folkerts, L., Burgi-Palomino, D., and Buckhout, E. 2016. A Look at the Northern Triangle of Central America in 2016: Sustained Violence and Displacement. Latin America Working Group: Action at Home for Just Policies Abroad. (http://www.lawg.org/action-center/lawg-blog/69-general/1709-a-lookat-the-northern-triangle-of-central-america-in-2016-sustained-violence-and-displacement ) .

Goldberg, E. 2014. 80\% of Central American Women, Girls are Raped Crossing into the U.S.Huffington Post. (http://www.huffingtonpost.com/2014/09/12/central-america-migrants-rape_n_5806972.h tml).

Gomez, Carlos. “Transnational Organized Crime:Let's Put Them out of Business.” United Nations Office of Drugs and Crime (UNODC), www.unodc.org/toc/en/reports/TOCTACentralAmerica-Caribbean.html.

Holmes, Seth M, et al. Fresh Fruit, Broken Bodies : Migrant Farmworkers in the United States. 1st ed., University of California Press, 2013.

Human Rights First. Failure to Protect: Biden Administration Continues Illegal Trump Policy to Block and Expel Asylum Seekers to Danger. 20 Apr. 2021, 
www.humanrightsfirst.org/resource/failure-protect-biden-administration-continues-illegal -trump-policy-block-and-expel-asylum.

Leyva-Flores, Rene, et al. "Migrants in Transit through Mexico to the US: Experiences with Violence and Related Factors, 2009-2015." PloS One, vol. 14, no. 8, 2019, p. E0220775.

López Ricoy, Ana, et al. "Exit as Care: How Motherhood Mediates Women’s Exodus From Violence in Mexico and Central America.” Violence Against Women, Mar. 2021, doi:10.1177/1077801221992875.

Mavroudi, E., \& Nagel, Caroline Rose. (2016). Global migration : patterns, processes, and politics. Routledge.

Menjívar, Cecilia. Enduring Violence : Ladina Women's Lives in Guatemala. 1st ed., University of California Press, 2011.

Morley, Priya. “The Impact of Anti-Black Racism on African Migrants at Mexico's Southern Border." The Black Alliance for Just Immigration, 2021, imumi.org/attachments/2020/The-Impact-of-Anti-Black-Racism-on-African-Migrants-atMexico.pdf.

Office for the Coordination of Human Affairs (OCHA) . "Surge in Violence against Girls and Women in Latin America and Caribbean - World." Plan International, plan-international.org/news/2020-05-19-surge-violence-against-girls-and-women-latin-a merica-and-caribbean.

Palmer, Emily, and Kirk Semple. “A Damning Portrait of Presidential Corruption, but Hondurans Sound Resigned.” The New York Times, The New York Times, 23 Mar. 2021, www.nytimes.com/2021/03/23/world/americas/honduras-juan-orlando-hernandez-drug-tri al.html. 
Resendiz, Julian. “Juarez Sees New Spike in Violence against Women.” BorderReport, BorderReport, 4 Jan. 2021, www.borderreport.com/hot-topics/border-crime/juarez-sees-new-spike-in-violence-agains t-women/.

Sanchez, Magaly R. "Insecurity and Violence as a New Power Relation in Latin America.” The Annals of the American Academy of Political and Social Science, vol. 606, 2006, www.jstor.org/stable/25097823.

Schmidt, Leigh Anne, and Buechler, Stephanie. "'I Risk Everything Because I Have Already Lost Everything': Central American Female Migrants Speak Out on the Migrant Trail in Oaxaca, Mexico.” Journal of Latin American Geography, vol. 16, no. 1, 2017, pp. $139-164$.

Shetty, Salil. "Most Dangerous Journey: What Central American Migrants Face When They Try to Cross the Border.” Amnesty International, Feb. 2014.

Shifter, Michael. "Countering Criminal Violence in Central America ." Council on Foreign Relations, Council Report, no. No. 64, 2012.

Sieff, Kevin, and Gabriela Martinez. "Mexican Police Charged in Massacre of Guatemalan Migrants near U.S. Border.” The Washington Post, WP Company, 3 Feb. 2021, www.washingtonpost.com/world/the_americas/mexico-tamaulipas-police-migrant-killing /2021/02/03/32c22274-65c7-11eb-8468-21bc48f07fe5_story.html.

Slack, J., Martínez, D.E., Lee, A.E. and Whiteford, S., 2016. The geography of border militarization: Violence, death and health in Mexico and the United States. Journal of Latin American Geogra- phy 15(1), pp.7-32. 
Speed, Shannon. Incarcerated Stories: Indigenous Women Migrants and Violence in the Settler-Capitalist State. The University of North Carolina Press, 2019.

United Nations. 2020 World Migration Report. 2020, www.un.org/sites/un2.un.org/files/wmr_2020.pdf.

United Nations. "The Impact of COVID-19 on Women." 9 Apr. 2020, reliefweb.int/sites/reliefweb.int/files/resources/policy-brief-the-impact-of-covid-19-on-w omen-en.pdf.

The Wilson Center, "Organized Crime in Central America: The Northern Triangle (No. 29)." Wilson Center, www.wilsoncenter.org/publication/organized-crime-central-america-the-northern-triangle - no-29.

Vera, Valeria. "Border Patrol's Not-So-Secret: the Normalized Abuse of Migrant Women on the U.S.-Mexico Border.” International Affairs Review, 2013.

VICE. YouTube, YouTube, 30 June 2021, www.youtube.com/watch?v=aaWIiAFvZy8.

World Bank. 2018. Towards Equal? Women in Central America. World Bank, Washington, DC. (C) World Bank. https://openknowledge.worldbank.org/handle/10986/30398 